\title{
Mentaliseringsbasert terapi for noviser og viderekomne
}
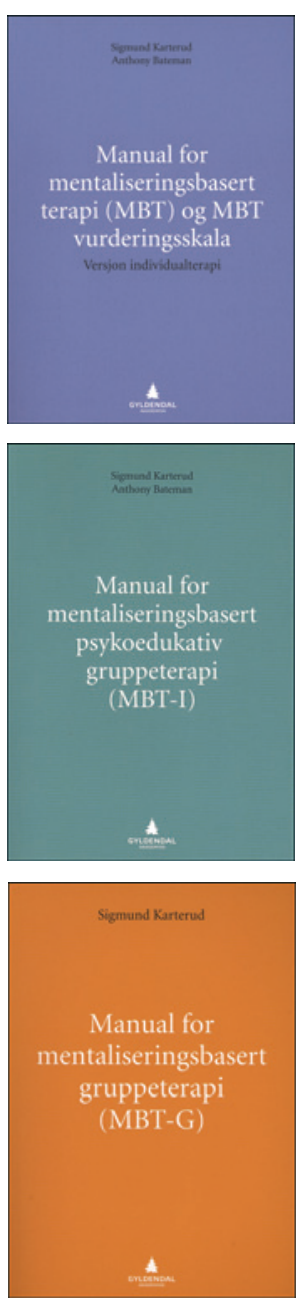

\section{Sigmund Karterud}

Manual for mentaliseringsbasert gruppeterapi (MBT-G)

260 s, tab, ill. Oslo: Gyldendal Akademisk, 2012. Pris NOK 325

ISBN 978-82-05-43016-7
Mentaliseringsbasert terapi (MBT) er en behandlingsform som i løpet av de siste fem årene har fått svært stor oppmerksomhet både internasjonalt og nasjonalt. Årsakene til dette er mange, men skyldes blant annet det tilgrunnliggende begrepet mentalisering.

Mentalisering er et multidimensjonelt begrep, men viser blant annet til hvordan vi fortolker egne og andres handlinger som ytringer for følelser, ønsker og behov. Mentalisering kan skje implisitt og eksplisitt, men mentaliseringsevnen vil vanligvis svekkes ved høy emosjonalitet. Mentaliseringteorien viser hvordan individet gjennom samhandling med en mentaliserende annen kan oppnå større grad av mentalisering, og i mentaliseringsbasert terapi er søkelyset rettet mot å tilrettelegge den terapeutiske relasjonen nettopp for det formålet. Mentaliseringsbasert terapi er en evidensbasert behandling som opprinnelig ble utviklet for behandling av pasienter med borderline-problematikk. Denne gruppen preges av hyppigere og mer intense tap av evnen til mentalisering. Siden er denne behandlingen videreutviklet til bruk også for andre populasjoner, og mentaliseringsbegrepet er dessuten blitt populært også innenfor andre områder.

Mentalisering er både et intuitivt enkelt, men samtidig komplisert begrep. Denne dobbeltheten gjør det til en krevende oppgave å beskrive og forklare. Karterud og Bateman klarer dette på en forbilledlig måte.
Bøkene har en stram struktur og et presist språk. Som titlene viser til, tar bøkene form av å være manualer for de ulike komponentene i mentaliseringsbasert terapi. I tillegg inneholder de beskrivelser og skalaer for vurdering av både pasienters mentaliseringsevne, terapeuters etterlevelse av terapiprinisippene og råd om hvorledes behandlingen kan tilpasses andre behandlingsomgivelser. Bøkene er oversiktlig oppbygd og dermed også lett å finne frem i. Dette er å forvente når man har som mål å skrive en manual, men bøkene fungerer på denne måten også som en fin måte å orientere seg i teori og metode for de som er ukjent med begrepene og behandlingen.

Psykiatrihistorien har vist oss at det historisk har vært til dels hatske utspill mellom de ulike teoriretningene innen psykiatri og psykologi. Det er derfor gledelig at forfatterne beskriver andre behandlingsformer, både kognitive og psykodynamiske, med respekt. Videre er det bra at de sammenlikner begreper og teknikker fra mentaliseringsbasert terapi med disse. Det fremhever likheter og forskjeller på en konstruktiv måte, noe som for eksempel fungerer svært godt i kapitlet om psykodynamisk formulering. Her viser forfatterne hvordan mer avgrensede formuleringer av pasientens kjerneproblematikk (også kalt kasusformulering) formuleres innenfor flere andre terapiretninger. Dette gjør det lettere for leseren å forstå både nytten med denne teknikken generelt og hvordan det kan gjøres i det praktiske terapeutiske arbeidet.

Bøkene inneholder også en rekke praktiske terapeutiske råd som gjelder for de fleste terapiformer. Forfatterne viser for eksempel til at «terapeuten står ovenfor en konstant fristelse til å sette bitene i puslespillet sammen, å gjøre ting meningsfulle i henhold til sin egen modell for mental fungering, kort og godt stå for mentaliseringen selv og avlevere sin forståelse og innsikt til pasienten». Dette er en kjent og vanlig feil hos nye terapeuter, men forfatterne viser her dessuten til at dette innen for mentaliseringsbasert terapi i tillegg blir forstått som «anti-mentaliserende».

Videre påpeker forfatterne, selv om - eller kanskje nettopp fordi - disse bøkene er manualer, at «psykoterapi er en kreativ virksomhet der terapeuter improviserer og de kan godt lykkes med å øke mentaliseringsevnen gjennom intervensjoner som ikke er dekket av denne listen».

Som leseren sikkert forstår, opplever anmelderen at det er vanskelig å finne klare svakheter med bøkene hver for seg. Det er likevel noe negativt at bøkene istedenfor å referere til hverandre, repeterer store deler av innholdet $\mathrm{i}$ de andre. Dette kan forsvares ved at ikke alle leser samtlige bøker, men det kunne uansett vært løst ved å ha samlet innholdet i bøkene til én bok. Men dette ødelegger ikke inntrykket av at forfatterne har klart å gi en god, samlet oversikt over begrepene og metoden, både for noviser og viderekomne.

Karterud hevder at «alle psykoterapier fremmer (forskjellige aspekter ved) pasienters mentaliseringsevne». Det kan selvsagt diskuteres, men det er i hvert fall sikkert at disse tre bøkene bidrar både til felles forståelse og et søkelys på evidensbasert behandling for en gruppe mennesker som sårt trenger og fortjener hjelp.

\section{Svein Øverland}

Arkimedes as

Trondheim 